\title{
Political Rights of Civil Servants in Indonesia*
}

\author{
Hernadi Affandi ${ }^{10}$
}

\begin{abstract}
This paper highlights the regulation of political rights of civil servants (PNS) in Indonesia based on the 1945 Indonesian Constitution. Political rights are part of human rights that shall be guarded and protected by the State in the form of legislation ranging from constitution to its implementing regulations. The presence of regulation is substantial for safeguarding the existence and implementing political rights possessed by citizens, including civil servants. However, in practice there are restrictions by the lawmaker towards the political rights of the civil servants in Indonesia. In this regard, this paper attempts to highlight two issues: first, the position of civil servants in Indonesia in the 1945 Indonesian Constitution; second, the regulation of the political rights of civil servants in the implementing regulations of the 1945 Indonesian Constitution.
\end{abstract}

Keywords: political rights, human rights, civil servants, 1945 Indonesian Constitution, implementing regulation.

\section{Pengaturan Hak Politik Pegawai Negeri Sipil di Indonesia}

\begin{abstract}
Abstrak
Tulisan ini menyoroti pengaturan hak Pegawai Negeri Sipil (PNS) di Indonesia berdasarkan Undang-Undang Dasar Negara Republik Indonesia tahun 1945 (UUD 1945). Hak politik merupakan bagian dari hak asasi manusia (HAM) yang harus dijaga dan dilindungi negara dalam bentuk pengaturan perundang-undangan mulai dari undang-undang dasar sampai dengan peraturan perundang-undangan pelaksananya. Kehadiran peraturan perundangundangan tersebut menjadi penting agar keberadaan maupun pelaksanaan hak politik yang dimiliki warga negara, termasuk PNS, dapat berjalan sebagaimana mestinya. Dalam praktiknya, terdapat pembatasan yang dilakukan oleh pembentuk undang-undang terhadap hak politik PNS di Indonesia. Berkaitan dengan hal tersebut, tulisan ini mencoba menyoroti dua persoalan: pertama, kedudukan PNS di Indonesia dalam UUD 1945; kedua, pengaturan hak politik PNS dalam peraturan perundang-undangan pelaksana UUD 1945.
\end{abstract}

Kata Kunci: hak politik, hak asasi manusia, pegawai negeri sipil, UUD 1945, peraturan perundang-undangan.

* This research was funded by DIPA BLU Fund, Universitas Padjadjaran.

10 Lecturer at Faculty of Law Universitas Padjadjaran, Jalan Dipati Ukur No. 35, Bandung, hernadi.affandi@unpad.ac.id, S.H. (Universitas Padjadjaran), LL.M. (Universiteit Utrecht), Dr. (Universitas Padjadjaran). 


\section{A. Introduction}

Political rights, as included in basic human rights (HAM), are fundamental as the embodiment of citizens' freedom. Political rights consist of, inter alia, the right to vote, the right to equal access to public service, the right to form political party, and the right to petition. ${ }^{1}$ The existence of such rights signify the relationship between state and individuals. ${ }^{2}$ Due to its importance, political rights must be guaranteed by state through its constitution.

A constitutional guarantee is vital for the maintenance and implementation of the political rights. In this case, the implementation of political rights must be fair and equal regardless of race, religion, ethnic group, social status, wealth, political opinion, or even a profession of a citizen. In other words, every citizen of a state shall be treated equally in the implementation of his/her political rights.

However in the actual practice, the guarantee and protection of political rights as stipulated in the 1945 Indonesian Constitution (hereinafter the Constitution) have not been implemented properly. It happens due to the restrictions in the implementing regulation of the Constitution. Consequently, the regulations and constitutional guarantee could not be fully implemented, thus, the political rights of the citizens become limited.

The restrictions issued by the lawmakers specifically target the civil servants in Indonesia. The restrictions are, among others, to restrict civil servants from joining political parties, House of Representative, and Senate. Such restrictions have marginalized and even limited the civil servants from enjoying their political rights. This condition shows that the implementation of political rights has not been implemented properly in accordance to the Constitution as the primary source of law in Indonesia.

This paper aims to identify two problems: First, what is the political status of civil servants as stipulated in the Constitution? Second, how are the political rights of civil servants being regulated in the implementing regulations of the Constitution?

\section{B. The Status of Civil Servants based on the Constitution}

The word "status" may have various meanings, linguistically. According to Soerjono Soekanto, "status" may refer to the position occupied by an individual within a particular social group, or could abstractly be defined as a place occupied by a person within a particular pattern. ${ }^{3}$ Meanwhile, R.M. Maclver defines "status" as a person's

1 Manfred Nowak, Introduction to the International Human Rights Regime, Leiden: Martinus Nijhoff Publishers Koninklijke Brill NV, 2003, p. 1.

2 Scott Davidson, Hak Asasi Manusia, translated by A. Hadyana Pudjaatmaka, Jakarta: Pustaka Utama Grafiti, 1994, p. 8.

3 Soerjono Soekanto, Sosiologi Suatu Pengantar, Jakarta: Rajawali Press, 1999, p. 264-265. 
or group's relative position in a particular hierarchical division. ${ }^{4}$

Based on the above definitions, in this paper, the status of civil servants could be defined as relative position occupied by several civil servants in the political map of Indonesia specifically with regards to the implementation of their political rights. The status of civil servants is related to how their political rights, especially the right to vote or be voted in general election, are regulated by the implementing laws. Before identifying the status of civil servants in the implementation of their political rights, it is important to identify the status of civil servants in the regulations, from the constitution to its implementing regulations. This will lead to the identification of whether or not there is a regulation on the function, task, or duty of civil servants, before and after the amendment of the Constitution.

The amendment of the Constitution is concerned with, among others, basic human rights, concept of legal state, and organs/bodies of the state. Before the amendment, the Constitution only consisted of 16 chapters, 37 articles, 49 paragraphs, 4 articles of transitional provision, and 2 articles of additional provision. After the amendment, it only consists of 21 chapters, 73 articles, 170 paragraphs, 3 articles of transitional provision, and 2 articles of additional provision. ${ }^{5}$ The amendment has made the basic human rights regulations even more detailed, compared with the pra-amended version.

The Constitution, even before the amendment, had already regulated the civil and political rights, apart from economic, social, and cultural rights. Civil and political rights were regulated in Article 27, 28, and 30, while economic, social, and cultural rights were regulated in Article 29, 31, 32, 33, and 34 which concentrated on religion, education, and culture. Meanwhile, in the amended version, the regulations of basic human rights have undergone a significant addition summarized into Article 28. Article 28 contains a comprehensive material on basic human rights which consisted into 10 articles (Article 28A to Article 28J).

However, none of those numerous articles feature a specific regulation concerning civil servants, even though civil servants are an inseparable component of the citizens whose rights and obligations are regulated and guaranteed in the Constitution. Before and after the amendment of the Constitution, there has been no strict regulation of the political status of civil servants in Indonesia. Therefore, in order to identify the status of civil servants, one could not only refer to the Constitution specifically, but also referring it to the general rights and obligations of citizens.

R.M. Maclver, Jaring Pemerintahan, translated by Harun Al Rasjid and Sutresna Sastradidjaja, Jakarta: Yasaguna, p. 106.

5 Secretary General of People's Consultative Assembly of Republic of Indonesia, Panduan Pemasyarakatan Undang-Undang Dasar Negara Republik Indonesia Tahun 1945 sesuai dengan Urutan Bab, Pasal, dan Ayat, Jakarta, 2006, p. 14. 
This is logical since civil servant is one of many kinds of professions or jobs available. This has put civil servants in an equal position with other citizens of other professions. The only distinct feature of the profession is its task of dealing with the affairs and administration of the state. However, the similar guarantee and protection of rights and duties as other citizens still need to be provided.

This lack of regulatory mechanism of the status of civil servants in the Constitution may signify several things:

1. Civil servants have not been given enough attention either from the formulators of the Constitution and People's Consultative Assembly during the amendment of the Constitution;

2. Civil servants are considered insignificant to be regulated in the Constitution;

3. The regulation of the civil servants could be conducted through lower regulatory mechanisms that are more flexible.

Similar condition is not only exist in Indonesia, but also in other countries such as United Kingdom. Civil servants in United Kingdom has not been regulated constitutionally since its constitution is unwritten. According to Bradley and Ewing, the civil servants of Britain have no specific legal status. ${ }^{6}$

United Kingdom does not even formulate the legal definition of civil servants. ${ }^{7}$ Civil servants in United Kingdom is defined through some doctrines. According to The Thomlin Commission, civil servants are, "The servants of the Crown, aside from the holder of judicial or political offices, who work in civil capacity and paid by the Parliament". 8

Similar to The Thomlin Commission, Bradley \& Ewing define civil servants as followed: ${ }^{9}$

"A servant of the Crown working in a civil capacity who is not: the holder of a political (or judicial) office; the holder of certain other offices in respect of whose tenure of office special provision has been made; a servant of the Crown in a personal capacity paid from the Civil List."

Based on the definition by Bradley and Ewing, civil servants does not include: ministers of the Crown; members of the armed forces (who are Crown servants but are not employed in a civil capacity); the police and those employed in local government and the National Health Service, even though they are all engaged in public services.

6 A.W. Bradley and K.D. Ewing, Constitutional and Administrative Law, $14^{\text {th }}$ edition, Essex: Pearson Longman, 2007, p. 283.

7 John Alder, General Principles of Constitutional and Administrative Law, New York: Palgrave Macmillan, 2002, p. 329.

8 Ibid.

9 A.W. Bradley and K.D. Ewing, Constitutional and..., Op.cit, p. 283. 
Meanwhile, according to S.A. de Smith, the civil servants in Britain possess several characteristics, among which is impartial public service. It means, "The civil service is non-partisan except in so far as it serves the Government in office. Its insulation from political involvement, and the security of tenure enjoyed by its members, have been the product of convention not of strict law". ${ }^{10}$ This is merely because the civil servants in Britain serve under the Queen. As a consequence, they are not allowed to participate in politics and have to be impartial and neutral.

This is quite different from the Netherlands which has specifically regulated the civil servants within its constitution. Article 109 of their constitution regulates the legal status of civil servants, "The legal status of public servants shall be regulated by Act of Parliament. Rules regarding employment protection and co-determination for public servants shall also be laid down by Act of Parliament". Based on such formulation, it is clear that the constitution of The Netherlands regulates about the civil servants, although rather generally; while the more specific regulations are to be made through implementing regulations.

According to the report of Ministere du Budget, des Competes Publics et de la Fonction Publique, in the Netherlands, civil servants have the equal status, including political status, as common citizens. ${ }^{11}$ Thus, the civil servants in The Netherlands could also participate in political party.

Based on the explanation above, it could be seen that different states treat and regulate the civil servants differently. Thus, the regulation regarding status, rights, obligations, and tasks of civil servants might also different from one state to another. This is of course an attempt to suit the different needs of states. As for Indonesia, there is a probability that the regulation of civil servants might also possess distinct characteristics compared to other states.

\section{The Regulation of Political Rights of Civil Servants in the Implementing Legislation of the 1945 Indonesian Constitution}

Since the re-implementation of the Constitution in July 5, 1959, the regulation of political rights of civil servants are included in these following laws:

1. Presidential Regulation Number 2 Year 1959 concerning Prohibition of Political Party Membership for Indonesian Civil Servants.

2. Law Number 18 Year 1961 concerning General Provisions on Employment.

3. Law Number 2 Year 1970 concerning Revocation of Presidential Regulation Number 2 Year 1959 concerning Prohibition of Political Party Membership for Indonesian Civil Servants.

10 S.A. de Smith, Foundation of Law Constitutional and Administrative Law, $2^{\text {nd }}$ edition, Middlesex: Penguin Education, 1975, p. 37.

11 Ministere du Budget, des Competes Publics et de la Fonction Publique, Administration and the Civil Service in the EU 27 Member States, 2008, p. 34. 
4. Law Number 8 Year 1974 concerning General Provisions on Employment.

5. Law Number 43 Year 1999 concerning Amendment of Law Number 8 Year 1974 concerning General Provisions on Employment.

Presidential Regulation Number 2 Year 1959 is a brief regulation consist of five articles. It states in its consideration that limitation and restriction for employers of state bodies is considered necessary for the improvement of its performance. It further states the reason and consideration why such restriction was made. Later, in Article 1 paragraph (1) of the Presidential Regulation, civil servants are grouped into:

1. Central Government Servants (Pegawai Pemerintah Pusat), whose payment is based on the F-Group of the P.G.P.N.-1955 and Regional Government Servants (Pegawai Pemerintah Daerah) whose payment is also based on the F-Group of the P.G.P.N.

2. All military and police officers.

3. Chief Director/Leader/Staff of corporation/foundation/organization/company, directly or indirectly owned by the State.

Based on the formulation of Article 1 above, it is clear that the definition of state officials has quite a wide scope. This means that state officials cover every employee that serves, either directly or indirectly, under the State.

Furthermore, Article 2 of the Regulation also contains prohibition of the involvement of state officials in political parties. The complete article is as followed, "The state servants as mentioned in Article 1 paragraph (1) are prohibited from joining political parties". Meanwhile, the definition of political party according to Article 1 paragraph (2) of the Regulation elaborates further that, "what is "political party' meant by this Regulation is any organization in contestation of the structural design or direction to be taken by the State".

By the consideration of this Presidential Regulation, this regulation specifically grants exception to some. It can be seen in Article 4 which states, "The President could issue a prohibition as mentioned in Article 2, towards civil servants of different groups than those mentioned in Article 1 paragraph (1)". This means that a civil servant, apart from the category regulated by Article 1 paragraph (1), is not excluded from the consideration of the Presidential Regulation. In other words, the prohibition stated in the Presidential Regulation could also apply to civil servants who belong to different groups than mentioned in Article 1 paragraph (1). This means civil servants of groups which not regulated in the Regulation are no exception to the prohibition as well.

However, the Regulation does not clearly state the definition of civil servants, which spawned the question: which group of civil servants not allowed to take a part in politics? Does the prohibition apply to all or only to military and police institutions? Does it mean civil servants are still allowed to participate in politics? Such issues are not answered by the Presidential Regulation. 
Indonesia was initially regulated civil servants in the Law Number 18 Year 1961 concerning General Provisions on Employment. The law was approved and signed by President Soekarno on July 21, 1961, and enacted by the Secretary of the State Mochd. Ichsan on July 21, 1961. The law clearly states to implement Article 27 and 28 of the 1945 Indonesian Constitution. It shows that the Law of Employment is related to the rights of the citizens as regulated by Article 27 and 28 of the Constitution.

The Law of Employment specifically provides a definition of civil servants as stated in Article 1 as followed:

(1) Civil servants are those who have fulfilled the requirements, appointed, or paid under governmental regulation, assigned the positions in state institution by state official or other state organizations.

(2) The requirements as mentioned in paragraph 1 consists of aspects of personality, loyalty, health, intelligence, capability, efficiency, and other requirements needed by the state institution as regulated by the Government.

Based on such formulation, it could be seen that civil servants are hired by the Government to work in state offices. However, the law does not clearly define what civil servant means. Contextually, civil servant could be defined as a position that is concerned with the governmental system. Thus, by such definition, civil servants also include military and police officers.

Article 10 stated that state servants (not only civil servants) are obliged to defend the ideology of the State. Thus, state servants have to put the interest of the State above all else. Furthermore, the article also regulates the restriction for state servants to join political parties.

Based on Article 10, it is clear that such restriction is mostly to be imposed on the civil servants. Similar kind of restriction had even been implemented once for military and police institutions; which could be found in the Law on Composition and Position of People's Consultative Assembly, House of Representative Council, and Regional House of Representative Council. On the contrary, there was no active restriction for civil servants to participate in political activities supported by political parties.

The law also states that if a restriction is going to be imposed on state servants as well on the civil servants, it only applies if the policy is highly required.

The Presidential Regulation Number 2 Year 1959 as mentioned above had lasted for about 10 years before being amended by Law Number 2 Year 1970 concerning Revocation of the Presidential Regulation Number 2 Year 1959 concerning Prohibition of Political Party Membership for Indonesian Civil Servants. This revocation of the Regulation marked the freedom of civil servants to join politics, unlike during the era of President Soekarno. 
There is a fundamental difference of involvement of civil servants between during the era of Soekarno where state servants, including civil servants, are prohibited from joining political activities and the era of Soeharto where the involvement of civil servants was encouraged. Another law regulating the civil servants is law Number 8 Year 1974 concerning General Provisions on Employment. Substantially, this Law contains an entirely different material from its preceding laws. This is evident in the preamble of the Law itself. This Law was strictly based on and implemented the 1945 Indonesian Constitution. This is also apparent in making the 1945 Indonesian Constitution and the decision of the People's Consultative Assembly as its basis of consideration.

According to Article 1 Number 1 of Law Number 8 Year 1974,"State servants are those who are regulated by the Laws, appointed by the ruling government and are assigned with the position of state officials or other positions by a certain regulation; and whose payment is regulated by law".

Furthermore, in Article 2, state servants are further divided into two groups: civil servants and Armed Forces of the Republic of Indonesia. Civil servants are further divided into three categories: Central Civil Servants, Regional Civil Servants, and Other Civil Servants. Meanwhile, in the explanation of Article 2 paragraph (2) sub point (a), it is elaborated that the definition of Central Civil Servants are:

1. Central Civil Servants whose payment is taken from the National Budget (APBN), who work in Departments, Non-Department Governmental Organizations, Secretariat of Highest Governmental Organizations, Regional Vertical Agencies, and the Court;

2. Central Civil Servants work in Service Companies (Perusahaan Jawatan);

3. Central Civil Servants assigned to Autonomy Regions;

4. Central Civil Servants who, based on a particular regulation, are assigned to other agencies like private company; and

5. Central Civil Servants assigned on other state affairs.

Apart from providing the definition and the division of civil servants, the basic principles law also strictly regulates the position of the civil servants. In Article 3, it is stated that, "Civil servant is an element of state apparatuses, servants to the state, and servants to the society, who-with loyalty to Pancasila, 1945 Indonesian Constitution, State, and Government, work for governmental office on state affairs".

Based on such requirements, it could be inferred that either civil servants or the Armed Forces of the Republic of Indonesia are elements of state apparatuses. Back then, the Armed Forces of the Republic of Indonesia consisted of Indonesian National Army (TNI) and the police. In other words, Armed Forces of the Republic of Indonesia which are state apparatuses, apart of the civil servants. 
Law Number 8 Year 1974 was then amended through Law Number 43 Year 1999 concerning Amendment of Law Number 8 Year 1974 concerning General Provisions on Employment. In this new Law, the definition of civil servants is further established in its Article 1 Number 1, "Civil servant is every member of the Republic of Indonesia who has fulfilled a set of requirements, is appointed by a state official, or is offered a position on public office, and whose payment is regulated by Law".

The definition and position of civil servants as regulated by Article 2 is a revision from the previous Law on Employment. The content of the Article 2 is:

(1) State Servants consist of:

a. Civil Servants;

b. Members of the Indonesian National Army; and

c. Members of the Police of the Republic of Indonesia (Polri)

(2) Civil servants as meant by paragraph (1) sub point a, consists of:

a. Central Civil Servants; and

b. Regional Civil Servants

(3) Apart from state servants as mentioned by paragraph (1), any state officials can also appoint any temporary servants.

In contrast with the previous Law on Employment, this new Law limits the position of state servants truly as servants to the state. As the consequence, state servants must be politically neutral impartial and indiscriminate in providing public service. Furthermore, state servants are also prohibited from becoming members or officials of political parties.

Meanwhile, General Commentary on the Law on Employment elaborates the reason to maintain the impartiality. It concerns primarily to preserve unity and cooperation also to maintain the focus and attention of the civil servants. Further to restrict the participation of the civil servants in political parties, the Law also strictly regulates that civil servants must be loyal and faithful to the Pancasila, 1945 Indonesian Constitution, and the Government. The civil servants also have to safeguard the unity of the nation.

Apart from the Law on Employment mentioned above, there is also another law that explicitly regulates the political rights of civil servants. This Law is related to general election of People's Consultative Bodies (Badan Permusyawaratan Rakyat), People's Consultative Assembly, House of Representative, and Regional House of Representative Members. Since the amendment of the 1945 Indonesian Constitution, this Law on the Composition and Position of MPR, DPR, and DPRD have been changed into Law on MPR, DPR, DPD, and DPRD (normally referred to as the MD3 law).

In 1969, Law Number 15 Year 1969 on the General Election of the Members of People's Consultative Bodies was issued. The Law no longer mentioned about the 
limitation of political rights for civil servants. Restriction and limitation, instead, is only enforced on the ex-member of Indonesian Communist Party (PKI) and the Armed Forces of the Republic of Indonesia. This was regulated in the Article 11 of the law, "The members of the Armed Forces of the Republic of Indonesia should not utilize the right to vote". ${ }^{12}$ Apart from not being allowed to vote, the Law also prevents the members of Armed Forces of the Republic of Indonesia from being elected.

Law Number 15 Year 1969 was then considered irrelevant with the condition of the time. It was amended by Law Number 4 Year 1975 concerning Amendment of Law Number 15 Year 1969 concerning General Election of People's Consultative Bodies Members. Later, this Law was also amended by Law Number 2 Year 1980 concerning Second Amendment of Law Number 15 Year 1969 concerning General Election of People's Consultative Bodies Members.

By that time, this amendment affected the right of citizens to participate in the legislative bodies, especially in the context of being able to vote and to be elected. However, the amendment did not directly affect the structure of civil servants. The regulation still allowed the civil servants to participate in politics.

Later on, Law Number 15 Year 1969 was also amended by Law Number 3 Year 1999 concerning General Election. This new Law was also amended by Law Number 4 Year 2000. Important issue emerged in this amendment was general election management became the primary duty and responsible of the General Election Commission (KPU), which was a neutral and impartial state body. One of the requirements of becoming a KPU member is not currently occupying a political or structural position in the structure of State Officials.

This law was then amended by Law Number 12 Year 2003 concerning General Election of the House of Representative Council, the Senate Council, the Local and Regional House of Representative Council Members. Specifically, this Law restates that civil servants, members of the Indonesian National Army, and members of the Police of the Republic of Indonesia who wished to participate the candidate for the election ought to resign their positions in the bodies. This was clear in Article 64 of the Law:

"Regional Representative Council candidates from civil servants, members of the Indonesian National Army, or members of the Police of the Republic of Indonesia, apart from being obliged to fulfill the requirements mentioned in Article 60 and Article 63 letter a, must first resign their positions as civil servants, members of Indonesian National Army, or members of the Police of the Republic of Indonesia".

12 Commentary on Article 11, as explained in General Commentary. 
This Law was amended by Law Number 10 Year 2008. This Law was signed by President Susilo Bambang Yudhoyono on March 31, 2008 and was enacted by the Minister of Law and Human Rights, Andi Matalatta. This amendment was expected to yield a more participative and democratic general election.

Similar with the previous Law, Law Number 10 Year 2008 also regulates the requirements to become candidates of Regional House of Representative Council, which are made separate from the membership of the House of Representative. The requirement become a member of Regional House of Representative Council are regulated in Article 12 letter k:

"Resigning as civil servants, members of the Indonesian National Army, officials for the State Owned Enterprises (BUMN), and/or other regionally owned enterprises, or other enterprises whose budget was provided by the State, proven by a resignation letter that cannot be withdrawn."

Further regulation of the political rights of civil servants is in Law Number 8 Year 2012 concerning General Election of House of Representative Council, Senate Council, and Regional House of Representative Council Members. This Law also regulates the requirements to participate in general election, as well as the requirement to be a candidate for election in People's House of Representative Council, Senate Council, Regional House of Representative Council for Province, and Regional House of Representative Council for Regency. This requirement, however, serve also as another restriction to limit the right and chance of a citizen from becoming a candidate. It means this is similar with the regulation of the previous laws. Even, the restriction involves a wider scope of concern as apparent in Article 12 and Article 51.

Apart from being regulated in various general election laws mentioned above, the political rights of the civil servants are also regulated in the Law on the Composition and Position of the People's Consultative Assembly, People's Representative Council, and Regional People's Representative Council and even in the MD3 Law. The regulation of political rights for civil servants during the new order began by the conception of Law Number 16 Year 1969 concerning Composition and Position of People's Consultative Assembly, People's Representative Council, and Regional People's Representative Council. The interesting aspect of this Law was the opening of the chance for civil servants to be elected as members of People's Consultative Assembly, House of Representative Council, or Regional House of Representative Council. A civil servant that somehow managed to be elected would not lose his status as a civil servant, and only temporarily deactivated.

The allowing of the civil servants to be members of consultative bodies with the temporary deactivating of their status as civil servants is quite fair. Thus, a civil servant elected for the consultative bodies would not permanently lose his status as a civil 
servant, either during the campaign, or even once he has been elected as such. The law indirectly gives a legal guarantee for civil servants to be candidates of People's Consultative Assembly, House of Representative Council, or Regional House of Representative Council. It is unfair if, during only the campaign phase of a general election, the civil servant has been already obliged to give his position as state official. If in case he manages only to get through the campaign, but loses the election; he would suffer a consequence of losing his position as a civil servant entirely.

Apart from civil servants, members of ABRI were also allowed to be members of People's Consultative Assembly, House of Representative Council, or Regional House of Representative Council. In case of Armed Forces of the Republic of Indonesia, it could be done through promotion, not general election. This is because the Law strictly regulates and differentiates the membership of the consultative bodies based on election and promotion. In conclusion, both military officers of ABRI and civil servants, by that time, could be elected for the consultative bodies.

The next Law related to the political rights of the civil servants is Law Number 22 Year 2003. This Law amended the Law Number 4 Year 1999 concerning Composition and Position of the People's Consultative Assembly, House of Representative Council, and Regional House of Representative Council, while also specifically regulated the structure of Regional Representative Council. As we know, Regional Representative Council is a quite new governmental structure in Indonesia compared to the People's Consultative Assembly, House of Representative Council, and Regional House of Representative Council. The MD3 Law does not specifically regulate the political rights of the state officials, specifically civil servants. However, this Law specifically mentioned the general election Law as a reference for its requirements. This is evident in Article 85 paragraph (2) sub point (c).

The next Law regulating the political rights of the civil servants is Law Number 27 Year 2009 concerning People's Consultative Assembly, House of Representative Council, or Regional House of Representative Council. The law regulates, inter alia, the restriction of the dual-occupying of positions for the members of People's Representative Council, Regional Representative Council, and Regional People's Representative Council, as already been stated in Article 208, 277, and 327.

From the explanation above, it is clear that the formulation of political rights of civil servants in Indonesia based on the 1945 Indonesian Constitution into a series of laws has undergone development and numerous revisions. As a consequence, the political rights of the civil servants have undergone development as such at one time they are allowed to participate in the politics, but another time they are banned from political activities (i.e. becoming members of representative/consultative bodies). 


\section{Conclusion}

The rights of civil servants have not been implicitely regulated in the 1945 Indonesian Constitution, either in its pra-amended or amended version. Before the amendment of the Constitution, the political rights of civil servants were protected and guaranteed in Article 27 and 28. After the amendment, however, the political rights are only generally regulated in human rights related articles such as Article $28 \mathrm{~A}$ to $28 \mathrm{~J}$. It is somehow unfortunate, since those articles does not implicitely formulate the definition, along with the accompanying rights, of civil servants in Indonesia. Thus, civil servants should have an equal rights than citizens in other professions.

The political rights of the civil servants are regulated by a series of Laws. Either ones that only specifically regulate civil servants, or other Laws. In these Laws, civil servants are allowed to perform their political rights, including the right to vote, to be elected, or to participate in political parties. However, in other cases the rights are limited, especially in the context of being able to be elected, and being able to participate in political parties.

The civil servants, through the regulation of the 1945 Indonesian Constitution and its implementing regulations, should be allowed individual participate in politics, despite belong to a neutral state body. The regulation of the political rights including the right to be elected, and to participate in political parties, should not be prohibited.

\section{References}

\section{Books}

Alder, John, General Principles of Constitutional and Administrative Law, Palgrave Macmillan, New York, 2002.

Bradley, A.W., and K.D. Ewing, Constitutional and Administrative Law, $14^{\text {th }}$ edition, Pearson Longman, Essex, 2007.

Davidson, Scott, Hak Asasi Manusia, translated by A. Hadyana Pudjaatmaka, Pustaka Utama Grafiti, Jakarta, 1994.

de Smith, S.A., Foundation of Law Constitutional and Administrative Law, $2^{\text {nd }}$ edition, Penguin Education, Middlesex, 1975.

Maclver, R.M., Jaring Pemerintahan, translated by Harun Al Rasjid and Sutresna Sastradidjaja, Yasaguna, Jakarta.

Nowak, Manfred, Introduction to the International Human Rights Regime, Martinus Nijhoff Publishers, Koninklijke Brill NV, Leiden, 2003.

Soerjono Soekanto, Sosiologi Suatu Pengantar, Rajawali Press, Jakarta, 1999. 


\section{Other Documents}

Ministere du Budget, des Competes Publics et de la Fonction Publique, Administration and the Civil Service in the EU 27 Member States, 2008.

Secretary General of People's Consultative Assembly of Republic of Indonesia, Panduan Pemasyarakatan Undang-Undang Dasar Negara Republik Indonesia Tahun 1945 sesuai dengan Urutan Bab, Pasal, dan Ayat, Jakarta, 2006.

\section{Legal Documents}

1945 Indonesian Constitution of Republic of Indonesia.

Law Number 18 Year 1961 concerning General Provisions on Employment.

Law Number 15 Year 1969 concerning General Election of People's Consultative/Representative Council Members (Pemilihan Umum Anggotaanggota Badan Permusyawaratan/Perwakilan Rakyat).

Law Number 16 Year 1969 concerning Composition and Position of People's Consultative Assembly, People's Representative Council, and Regional People's Representative Council (Susunan dan Kedudukan Majelis Permusyawaratan Rakyat, Dewan Perwakilan Rakyat dan Dewan Perwakilan Rakyat Daerah).

Law Number 2 Year 1970 concerning Revocation of Presidential Regulation Number 2 Year 1959 concerning Prohibition of Political Party Membership for Indonesian Civil Servants (Larangan Keanggotaan Partai-partai Politik bagi Pejabat Negeri Republik Indonesia).

Law Number 8 Year 1974 concerning General Provisions on Employment.

Law Number 4 Year 1975 concerning Amendment of Law Number 15 Year 1969 concerning General Election of People's Consultative/Representative Council Members.

Law Number 5 Year 1975 concerning Amendment of Law Number 16 Year 1969 concerning Composition and Position of People's Consultative Assembly, People's Representative Council, and Regional People's Representative Council.

Law Number 2 Year 1980 concerning Second Amendment of Law Number 15 Year 1969 concerning General Election of People's Consultative/Representative Council Members.

Law Number 1 Year 1985 concerning Amendment of Law Number 15 Year 1969 concerning General Election of People's Consultative/Representative Council as amended by Law Number 4 Year 1975 and Law Number 2 Year 1980.

Law Number 2 Year 1985 concerning Amendment of Law Number 16 Year 1969 concerning Composition and Position of People's Consultative Assembly, People's Representative Council, and Regional People's Representative Council as amended by Law Number 5 Year 1975. 
Law Number 5 Year 1995 concerning Amendment of Law Number 15 Year 1969 concerning General Election of People's Consultative/Representative Council as amended by Law Number 1 Year 1985 and Law Number 2 Year 1980.

Law Number 3 Year 1999 concerning General Election.

Law Number 4 Year 1999 concerning Composition and Position of People's Consultative Assembly, People's Representative Council, and Regional People's Representative Council.

Law Number 43 Year 1999 concerning Amendment of Law Number 8 Year 1974 concerning General Provisions on Employment.

Law Number 4 Year 2000 concerning Amendment of Law Number 3 Year 1999 concerning General Election.

Law Number 12 Year 2003 concerning General Election of People's Representative Council, Regional Representative Council, and Regional People's Representative Council Members.

Law Number 10 Year 2008 concerning General Election of People's Representative Council, Regional Representative Council, and Regional People's Representative Council Members.

Law Number 27 Year 2009 concerning People's Consultative Assembly, People's Representative Council, Regional Representative Council, and Regional People's Representative Council.

Law Number 8 Year 2012 concerning General Election of People's Representative Council, Regional Representative Council, and Regional People's Representative Council Members.

Presidential Regulation Number 2 Year 1959 concerning Prohibition of Political Party Membership for Indonesian Civil Servants. 